DOI: https://doi.org/10.32839/2304-5809/2021-3-91-15

УДК 811.11

\title{
ОСМИСЛЕННЯ ФОРМУВАННЯ АНГЛОМОВНОГО ДІЛОВОГО ДИСКУРСУ
}

\begin{abstract}
Анотація. Стаття покликана осмислити формування англомовного ділового дискурсу через призму становлення дискурсу у різних наукових галузях. Кардинальне розмежування понять “текст» та «дискурс» дає змогу краще зрозуміти та дослідити функційність останнього. Діловий дискурс розглядається з точки зору інституційності. Інституційний дискурс виділяеться за допомогою цілей та учасників спілкування. Метою ділового дискурсу є встановлення взаємовигідних ділових відносин. Інституційний діловий дискурс осмислюеться як складний об’ект, що має у своєму арсеналі ряд особливих конституційних та когнітивно-лінгвістичних особливостей, які відрізняють його від інших видів дискурсу.
\end{abstract}

Ключові слова: дискурс, діловий дискурс, інституційний дискурс, поняття.

Liu Yu

National Pedagogical Dragomanov University

\section{UNDERSTANDING THE FORMATION OF ENGLISH BUSINESS DISCOURSE}

Summary. The article is designed to comprehend the formation of English-language business discourse through the prism of the formation of discourse in various scientific fields. The radical distinction between the concepts of «text» and «discourse» makes it possible to better understand and explore the functionality of the latter. Business discourse is viewed in terms of institutionality. Institutional discourse is distinguished by the goals and participants of communication. The boundaries of discourse are thus established in relation to a certain period of time, the scope of human practice, the field of knowledge, the typology of the text and some other parameters. The purpose of business discourse is to establish mutually beneficial business relationships. Institutional business discourse is understood as a complex object that has in its arsenal a number of special constitutional and cognitive-linguistic features that distinguish it from other types of discourse. Discourse is expressed as a linguistic expression, ordered and systematized in the ideological and national mentality. Scientific understanding of business discourse is distinguished from the point of view of the research sphere and involves the development of the definition of a certain unit of discursive analysis. Status-role relations define business discourse as institutional, in which system-forming features are clearly outlined. In our article, we consider and characterize the features of institutional discourse, which clearly illustrate the interaction between representatives of certain institutions and the people who turn to them. The outlined features include participants (status-role roles), conditions, organization, methods of communication. Institutional discourse differs from personal by the presence of clichés and stencil communication.

Keywords: discourse, business discourse, institutional discourse, concepts.

Постановка проблеми. В даний час

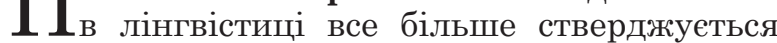
висунуте фрранцузьким культурологом М. Фуко уявлення про дискурс як узагальнення всього сказаного [6, с. 65]. Влучним є вислів М.Л. Макарова, що «широке вживання дискурсу як родової категорії по відношенню до понять мова, текст, діалог сьогодні все частіше зустрічається в лінгвістичній літературі, в той час як у фрілософрській, соціологічній або психологічній термінології воно вже стало нормою» [4, с. 50].

Як зазначає Н.Д. Кіщенко, поняття дискурсу було першочергово сфрормоване у фрілософріi та мистецтвознавстві в період кризи фрілософіiі структуралізму та ранньої пост структуралістської фрілософрії кінець 60-х - початок 70-х років та стало опорним поняттям у філософрських системax М. Фуко та Ж.-Ф. Ліотара, хоча витоків теорії дискурсу слід шукати в дослідженнях німецької школи П. Хартмана та П. Вундерліха, а також більш віддалених у роботах М. Бахтіна [2, с. 46].

Концепція М. Фуко лягла в основу розвитку німецької школи дискурсивного аналізу (У. Маас, 3. Егер, Ю. Лінк, Р. Водак), де пріорітетною стала вже власне мовна сторона цього процесу. Як зазначає В.Є. Чернявська, дискурс в роботах цих вчених розглядається як мовне вираження суспільної практики, впорядковане і систематизова- не особливим чином використання мови, за яким стоїть особлива, ідеологічно і національно історично обумовлена ментальність [7, с. 150]. 3 ціеї позиції У. Маас, наприклад, визначає дискурс як відповідну мовну формацію по відношенню до соціально та історично певної загальновживаної практики [8, с. 204]. Межі дискурсу встановлюються, таким чином, щодо певного періоду часу, сфрери людської практики, області знань, типології тексту і деяких інших параметрів. У лінгвістиці тексту 70-х років терміни «дискурс» і «текст» зазвичай ототожнювалися, що пояснювалося відсутністю в деяких європейських мовах слова, еквівалентно фрранко-англійському «дискурс», його змушені були замінити назвою «текст». Проте в кінщі 70-х - на початку 80-х рр. помітними стають тенденції до їх розмежування. У результаті диференціюються поняття текст і дискурс [3, с. 47].

Аналіз останніх досліджень і публікацій. У сучасній фрілології, зокрема в лінгвістичній теорії тексту, термін «дискурс» використовується достатньо активно, однак однозначного тлумачення він не має. Визначення поняття «дискурс» 3 різною мірою лінгвістичності пропонувалося як зарубіжними (В. Кох, Е. Бенвеніст, А. Греймас, П. Серіо, Ж. Курте, Ж Ж.-К. Коке, Ч. Філлмор, Т. ван Дейк), так і російськими дослідниками (Н. Арутюнова, В. Костомаров, Н. Бурвікова, М. Димар- 
ський). На початку 90-х років з'являеться чимало досліджень $з$ аналізу дискурсу. П. Серіо, посилаючись на книгу Д. Манжене, розглядае вісім визначень дискурсу.

Отримавши свій розвиток в зарубіжній лінгвістиці в працях Е. Бенвеніста, 3. Харріса i М. Фуко, дискурс спочатку був складний, комплексний і багатоаспектний об'єкт дослідження. Послідовник Ф. де Сосюра Е. Бенвеніст розумів під дискурсом мову, що привласнюеться мовцем, протиставляючи їі об'єктивній розповіді. Підкреслюючи у своїх дослідженнях «саме акти, ситуації, в яких він реалізуеться, засоби його здійснення», він відзначав, що «мовець привласнюе формальний апарат мови і висловлюе свій статус мовця за допомогою спеціальних показників, з одного боку, і за допомогою особистих допоміжних прийомів, з іншого. ... В цілому ж акт висловлювання характеризуеться підкресленням усталеності в промові ставлення до партнера, яким би він не являвся реальним чи уявним, індивідуальним або колективним» [6, с. 313-316].

Виділення не вирішених раніше частин загальної проблеми. Уявлення про дискурс як одиницю вищого, ніж текст, рівня дозволяє розмежовувати його. Сучасний лінгвістичний аналіз дискурсу передбачає вирішення проблеми типології дискурсу. Питання про класифікацію, типи й різновиди дискурсу виходять на перший план. Велика кількість різних типологій дискурсу, пропонованих сучасними дослідниками, є наслідком того, що в основу класифікації покладено різні принципи.

В наш час отримали практичну розробку чи були теоретично виділені політичний, діловий, масово-інформаційний та інші типи дискурсу [3, с. 49]. Наукове осмислення такого об'ємного об'єкта, як дискурсивний простір, потребує, з одного боку, чіткого розмежування дослідницької сфери, а з другого - передбачае розробку робочого визначення конкретної одиниці дискурсивного аналізу [3, с. 49].

Мета статті. Метою статті $є$ висвітлення поняття інституційності ділового дискурсу та його функціонування в лінгвістиці.

Виклад основного матеріалу. Звернемося до поняття інституційності, яке являе собою невід'ємний параметр дискурсивної інтеракції. Інституційний дискурс використовуе визначену систему профресійно-орієнтованих знаків або, іншими словами, має власну мову (спеціальну лексику, фрразеологією). Людина вступає в той чи інший дискурсивний простір не тільки в певній соціальній ролі (що включає або припускае тип соціального інституту), але і з певною метою. Інституційний дискурс являеться гранично широким поняттям, що охоплюе як мовну систему (ту їі частину, яка специфічно орієнтована на обслуговування певної ділянки комунікацій), так і мовну діяльність (сукупність лінгвістичних та екстралінгвістичних чинників) та текст.

Інституційний дискурс являе собою спрощення в заданих рамках статусно-рольових відносин $[2$, с. 14$]$. У сучасному суспільстві існують такі види інституційного дискурсу, які отримали визначальну дослідницьку оцінку: політичний, дипломатичний, адміністративний, юридичний, військовий, педагогічний, релігійний, містич- ний, медичний, діловий, рекламний, спортивний, науковий, сценічний та масово-інформаційний. Інституційний дискурс виділяеться на підставі двох системоутворюючих ознак: цілі та учасники спілкування [2, с. 15]. наприклад, метою політичного дискурсу $є$ завоювання і утримання влади, педагогічного дискурсу - соціалізація нового члена суспільства, ділового дискурсу встановлення взаємовигідних ділових відносин між організаціями і т.д. Основними учасниками інституційного дискурсу є представники певного інституту та люди, які звертаються до них.

Традиційно виділяють чотири ознаки інститущійного дискурсу:

1) конституційний;

2) інституційний;

3) який має ознаки типу інституційного дискурсу;

4) нейтральний.

Ознаки конституційного дискурсу включають учасників, умови, організацію, способи та матеріал спілкування, тобто людей в їх статусно-рольових та ситуаційно-комунікативних амплуа, сферу спілкування та комунікативне середовище, мотиви, цілі, стратегіі, канал, режим, тональність, стиль та жанр спілкування і, нарешті, знакова тіло спілкування (тексти i/або невербальні знаки) [2, с. 15]. Вони отримали досить повне висвітлення в роботах із соціолінгвістики і прагмалінгвістики (Hymes, 1974; Fishman, 1976; Brown, Fraser, 1979; Белл, 1980; Богданов, 1990; Карасик, 1992; Макаров, 1998).

Ознаки інституційності фріксють рольові характеристики мовця та слухача, типовий хронотоп, символічні дії, трафраретні жанри і мовні кліше.

Таким чином, інституційне спілкування - це комунікація в своєрідних масках [4, с. 66]. Саме трафраретність спілкування принципово відрізняе інститущійний дискурс від персонального. Специфріка інституційного дискурсу розкриваеться в його типі, тобто в типі громадського інституту, який в колективній мовній свідомості позначений особливим іменем, узагальнено в ключовому концепті цього інституту (політичний дискурс - влада, педагогічний - навчання, релігійний - віра, юридичний - закон, медичний - здоров'я і т.д.), пов'язуючи його 3 певними функціями людей, спорудами, збудованими для виконання даних фонкцій, загальними ритуалами і поведінковими стереотипами, міфологемами, а також текстами, виробленими цим соціальним середовищем [5, с. 77]. Нейтральні ознаки інституційного дискурсу включають в себе загальнодискурсивні характеристики, типові для будь-якого спілкування, особистісно-орієнтовані ознаки, а також ознаки інших типів дискурсу, які проявляються "на чужій території, тобто транспоновані ознаки (наприклад, елементи проповіді як частини релігійного дискурсу в політичному, реклами - в медичному, наукового дискурсу - в педагогічному) [7, с. 17].

Комунікативні кліше в рамках інституційного дискурсу є своєрідними ключами для осмислення всіеї системи відносин у відповідному інституті.

Інституційний ділової дискурс - складний об'єкт, який має ряд інститущійних і когнітивно лінгвістичних особливостей, що відрізняють його від всіх інших типів дискурсу. Інституційний діло- 
вий дискурс-це процес творчої відповідності нормі, яка диктуеться і пізнається через складну і багатовимірну «професійну» картину світу, актуалізовану через базові поняття ділової культури, продесійноспрямовані ідеї та концепти, норми інституційної та міжособистісної поведінки, що детермінують ділове спілкування, ціннісні орієнтащії; схеми, фррейми стереотипних ситуацій, формули; спеціальний тезаурус (наприклад, слова-сигнали).

Все це знання, які вербалізуються в текстах за профресійним спрямуванням на лінгвокогнітивному рівні [4, с. 44]. До особливостей офріційно-ділового дискурсу відносяться стабільність, традиційність і стандартизованість оскільки сферою його застосування є ділові відносини між людьми, установами та державами. Оскільки офіційно-діловий дискурс, як вже зазначалося, характеризується суворою точністю, об'єктивністю, конкретністю, лаконічністю, відсутністю образності та емоційності, то і вибір засобів для нього буде визначатися цими ж особливостями. Зокрема, вживання інтернаціональних лексичних одинищь не буде продиктовано прагненням до реалізащії основних прагматичних установок, оскільки виражений в офріційно-діловому стилі зміст має виключати двозначність і можливість різночитання.

Висновки і пропозиції. Незважаючи на величезний дослідницький інтерес до особливостей профресійної комунікації, цілісна когнітивна теорія продукування та розуміння дискурсу в окремих соціальних інститутах (а саме, в сучасному бізнес-співтоваристві) не досліджені.

Недостатньо вивчені і вимагають спеціального дослідження питання співвідношення різних когнітивних моделей і стратегій мовленнєвої діяльності в про процесі дискурсивного взаємодії. У світлі сказаного ми приходимо до висновку про те, що інституційний діловий дискурс, як правило, виділяеться своєю відносною стійкістю та замкнутістю. Це обумовлено його специфічною спрямованістю: міжнародні договори, державні акти, юридичні закони, постанови, статути, інструкції, службові листування, ділові папери і т. д. Не дивлячись на відмінності в змісті та різноманітності жанрів, інституційний діловий дискурс в цілому характеризуеться рядом спільних рис. До них, зокрема, відносяться:

1) стислість, компактність викладу, помірне використання мовних засобів;

2) стандартне розташування матеріалу, нерідко обов'язковість вживання властивих цьому стилю кліше;

3) широке використання термінології, номенклатурних найменувань, наявність особливого запасу лексики та фразеології, включення в текст складноскорочених слів, абревіатур.

\section{Список літератури:}

1. Бахтин М.М. Проблема речевых жанров : Собр. соч. : в 7 т. Т. 5. Москва : Рус. слов., 1997. 732 с.

2. Карасик В.И. О типах дискурса // Языковая личность: институциональный и персональный дискурс : Сб. науч. тр. Волгоград : Перемена, 2000. С. 5-20.

3. Кіщенко Н.Д. Вербалізація концепту WISDOM/МУДРІСТЬ у дискурсі англомовної авторської казки : дис. ... канд. фрілол. наук : 10.02.04 «Германські мови». Київ, 2017. 189 с.

4. Макаров М.Л. Основы теории дискурса. Москва, 2003. 50 с.

5. Хэррис 3.С. Метод в структуральной лингвистике / В.А. Звегинцев. История языкознания XIX и XX вв. в очерках и извлечениях. 3 изд. Т. 2, Москва, 1965. 180 с.

6. Фуко М. Порядок дискурса / Воля к истине. Москва, 1996. 820 с.

7. Чернявская В.Е. Дискурс как объект лингвистических исследований / В.Е. Чернявская. Текст и дискурс. С.-Петербург, 2001. 234 с.

8. Maas U. Als der Geist der Gemeinschaft eine Sprache fand. Sprache im Nationalsozialismus. Opladen, 1984.86 p.

\section{References:}

1. Bahtin M.M. (1997) Problema rechevyih zhanrov [The problem of speech genres]: Sobr. soch.: v 7 t. T. 5 . Moscow: Rus. slov., 732 p.

2. Karasik V.I. (2000) O tipah diskursa // Yazyikovaya lichnost: institutsionalnyiy i personalnyiy diskurs [On the types of discourse // Linguistic personality: institutional and personal discourse]: Sb. nauch. tr. Volgograd: Peremena, pp. 5-20.

3. Kishchenko N.D. (2017) Verbalizatsiya kontseptu WISDOM/MUDRIST' u diskursi anglomovnoyi avtorskoyi kazky [Verbalization of the WISDOM/WISDOM concept in the discourse of an English-language author's fairy tale]: dis. ... kand. filol. nauk: 10.02.04 "Germanski movy". Kyiv, 189 p.

4. Makarov M.L. (2003) Osnovy teorii diskursa [Foundations of Discourse Theory]. Moscow, $50 \mathrm{~s}$.

5. Herris Z.S. (1965) Metod v strukturalnoy lingvistike / V.A. Zvegintsev. Istoriya yazyikoznaniya XIX i XX vv. v ocherkah i izvlecheniyah [Method in Structural Linguistics / History of Linguistics of the $19^{\text {th }}$ and $20^{\text {th }}$ centuries. in essays and extracts]. 3 izd., t. 2 . Moscow, 180 p.

6. Fuko M. (1996) Poryadok diskursa [Discourse order]. Volya k istine. Moscow, 820 p.

7. Chernyavskaya V.E. (2001) Diskurs kak ob'ekt lingvisticheskih issledovaniy [Discourse as an object of linguistic research]. Tekst i diskurs. S.-Peterburg, $234 \mathrm{p}$.

8. Maas U. (1984) Als der Geist der Gemeinschaft eine Sprache fand. Sprache im Nationalsozialismus. Opladen, 86 p. 